Alfia Patandungan, Syamsidar HS, dan Aisyah Fitoremediasi Tanaman Akar Wangi (Vetiver zizanioides) terhadap Tanah Tercemar Logam Kadmium (Cd) pada Lahan Tpa Tamangapa Antang Makassar

\title{
FITOREMEDIASI TANAMAN AKAR WANGI (Vetiver zizanioides) TERHADAP TANAH TERCEMAR LOGAM KADMIUM (Cd) PADA LAHAN TPA TAMANGAPA ANTANG MAKASSAR
}

\author{
Alfia Patandungan, Syamsidar HS., dan Aisyah \\ Jurusan Kimia, Fakultas Sains dan Teknologi, UIN Alauddin Makassar \\ Email: aisyah@uin-alauddin.ac.id
}

\begin{abstract}
One example of soil contamination on land landfill is (TPA) Makassar. The method of prevention is phytoremediation of the contaminated land. This study examined the ability of the plant will vetiver (Vetiver zizanioides) in reducing the levels of $\mathrm{Cd}$ in the soil. To increase the potential of these plants to remediate $\mathrm{Cd}$, the soil where the plants grow is combined with compost in which bacteria within the compost might improve the absorption of $C d$. Planting medium used is pure soil and compost from Tamangapa Makassar. Research carried out for 28 days with a variation of the study. The composition of the media that the contaminated soil (TT) metal kadmium $(C d)$ and compost $(K)$ with a ratio of $100 \%(T T): 0 \mathrm{~K}, 5(T T): 1(K), 4.5(T T)$ : $1.5(K)$ and $4(T T): 2(K)$. The results shwed that vetiver plants were able to absorb Cd of 0,298 $\mathrm{mg} / \mathrm{Kg}$ so it can be concluded that the composition of the planting medium with a combination of compost less significant because the combination of the contaminated soil with compost are less precise in helping vetiver plants accumulate or reduce metal pollution cadmium in contaminated soil Tamangapa Antang Makassar.
\end{abstract}

Keywords: phytoremediation, a combination of compost, cadmium, plantvetiver (vetiver zizanioides)

\section{PENDAHULUAN}

Salah satu kekayaan Indonesia adalah memiliki tanah yang subur, namun seiring perkembangan zaman kesuburan tanah di Indonesia sebagian besar telah tercemar disebabkan oleh berbagai kegiatan manusia yang menimbulkan efek berupa limbah sehingga mencemari tanah. Penyebab pencemaran tanah diakibatkan oleh pesatnya perkembangan industri, pembangunan perumahan, pembangunan hotel dan lain sebagainya yang menghasilkan polutan/pencemar bagi tanah, air maupun udara.

Pencemaran tanah merupakan masuk atau dimasukannya zat atau sesuatu ke dalam tanah baik secara sengaja maupun tidak sengaja yang merusak tatanan kimia tanah sehingga berubah dari kondisi awalnya. awalnya. Pencemaran tanah sebagian besar disebabkan oleh limbah padat berupa sampah baik sampah organik maupun sampah anorganik. Sampah-sampah ini kemudian 
Affia Patandungan, Syamsidar HS, dan Aisyah Fitoremediasi Tanaman Akar Wangi (Vetiver zizanioides) terhadap Tanah Tercemar Logam Kadmium (Cd) pada Lahan Tpa Tamangapa Antang Makassar

masuk menyerap ke dalam tanah hingga beratus-ratus tahun lamanya karena tidak dapat terurai dalam tanah sedangkan yang dapat terurai kemudian akan menjadi tanah humus. Polutan yang terus menerus dalam tanah akan masuk ke dalam rantai makanan melalui tumbuhan sehingga menyebabkan menurunnya kualitas organisme (Bahtiar, 2007: 6).

Salah satu contoh kasus pencemaran tanah terjadi pada lahan TPA Tamangapa-Antang Makassar, selain merusak tatanan kimia tanah, pencemaran juga berdampak pada masyarakat sekitar lahan TPA Tamangapa-Antang Makassar yang menimbulkan bau yang kurang sedap dari dampak penumpukan sampah tersebutsehingga memerlukan suatu alternatif untuk mengurangi pencemaran tanah utamanya pencemaran dari berbagai logam berat.Salah satu logam berat yang ada dalam sampah yaitu logam $\mathrm{Cd}$ yang beresiko tinggi terhadap pencemaran lingkungan. Beberapa jenis sampah yang mengandung logam Cd seperti plastik, kaleng-kaleng dan berbagai logam-logam yang tidak dapat terurai oleh mikroba tanah.

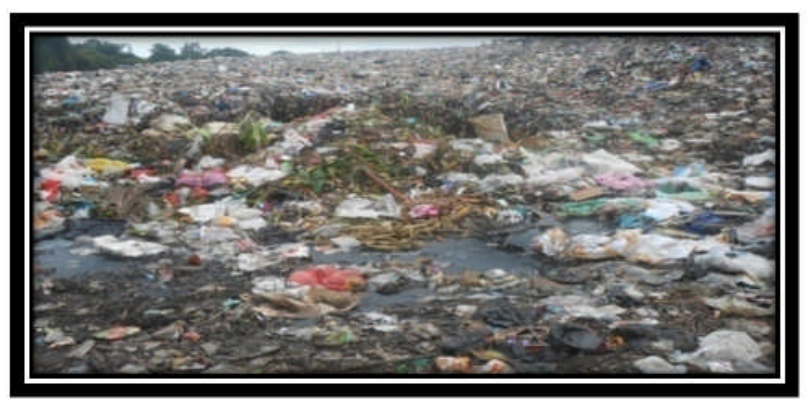

Gambar 1. TPA Tamangapa Antang Makassar

Dari penelitian yang dilakukan oleh (Zubair dan Haeruddin, 2012: 6) di TPA Tamangapa Makasasar diketahui bahwa komponen sampah yang terbesar adalah jenis sampah organik mencapai $80,71 \%$ sedangkan komponen sampah anorganik sebesar 9,23\%. Karakteristik timbulan sampah dan komposisi sampah yang ada di TPA Tamangapa Makassar dapat dilihat pada Tabel 1.

Beberapa alternatif untuk penanggulangan pencemaran tanah diantaranya penanggulangan pencegahan pencemaran terdiri atas reduce (mengurangi penggunaan), reuse (pemakaian kembali), recyle (daur ulang), fitoremediasi dan bioremediasi (pemanfaatan mikroorganisme). Salah satu metode yang efektif untuk penanggulangan pencemaran pada lahan TPA Tamangapa Makassar yaitu fitoremediasi. fitoremediasi merupakan penggunaaan tumbuhan untuk memperbaiki, mengurangi ataupun memulihkan lahan tercemar berbagai polutan (Irawanto, 2010, hal: 2). 
Alfia Patandungan, Syamsidar HS, dan Aisyah Fitoremediasi Tanaman Akar Wangi (Vetiver zizanioides) terhadap Tanah Tercemar Logam Kadmium (Cd) pada Lahan Tpa Tamangapa Antang Makassar

Tabel 1. Komposisi Sampah di TPA Tamangapa Makassar

\begin{tabular}{ccc}
\hline Komposisi Sampah & Komposisi Sampah (\%) & Timbulan Sampah (ton) \\
\hline Organik & 80,71 & 417.85 \\
Plastik & 9,23 & 47,77 \\
Kertas & 7,03 & 36,38 \\
Kain & 0,03 & 0,13 \\
Kayu & 0,17 & 0,86 \\
Kaca & 0,22 & 1,14 \\
Kaleng / besi & 2,12 & 10,97 \\
Karet & 0,50 & 2,60 \\
Jumlah & 100 & 517,70 \\
\hline
\end{tabular}

Upaya mengatasi pencemaran logam berat pada lahan TPAAntang Makassar dengan fitoremediasi merupakan suatu cara yang efektif karena tidak memerlukan biaya yang cukup mahal dan caranya pun secara alami yaitu dapat diterapkan secara langsung pada lahan yang tercemar. Dari beberapa penelitian sebelumnya teknik fitoremediasi ini sangat efektif diterapkan walaupun pada lahan yang telah terkontaminasi berat dengan berbagai macam polutan. Hal ini disebabkan karena beberapa tanaman tidak hanya mampu menyerap satu jenis polutan tetapi lebih dari satu polutan.

Keunggulan menggunakan tanaman dalam fitoremediasi adalah tanaman lebih tahan lama dibandingkan mikroorganisme pada konsentrasi dan kontaminan yang cukup tinggi dan mampu menyerap serta mengurangi toksitas logam berat jauh lebih cepat tanpa merusak pertumbuhan dari tanamn. Metode fitoremediasi ini mengalami perkembangan pesat karena terbukti lebih relatif ekonomis dibanding dengan metode lainnya. Dari beberapa penelitian sebelumnya metode fitoremediasi ini sangat tepat digunakan pada lahan TPA dengan penanaman tanaman hiperakumulator pada lapisan terakhir TPA ataupun menggunakan sistem wetland (lahan basah) bagi air lindih (Irawanto, 2010, hal: 2).

Mekanisme kerja fitoremediasi terdiri dari beberapa tahapan dalam mereduksi berbagai zat pencemar/polutan diantaranya:

1. Phytoacumulation (phytoextraction) merupakan proses tumbuhan/tanaman dalam menarik zat kontaminan dalam tanah dan diakumulasikan di sekitar akar tumbuhan kemudian meneruskan senyawa tersebut ke bagian tumbuhan seperti, akar, batang dan daun tanaman. Kontaminan dihilangkan dengan cara memanen tanaman. 
Affia Patandungan, Syamsidar HS, dan Aisyah Fitoremediasi Tanaman Akar Wangi (Vetiver zizanioides) terhadap Tanah Tercemar Logam Kadmium (Cd) pada Lahan Tpa Tamangapa Antang Makassar

2. Rhizofiltration (rhizo: akar) merupakan proses akar tumbuhan dalam mengadsorpsi zat kontaminan untuk menempel pada akar.

3. Phytostabilization merupakan proses tumbuhan dalam menarik zat-zat kontaminan tertentu ke bagian akar tanaman karena tidak dapat diteruskan ke bagian lain tanaman..Zat-zat tersebut menempel erat (stabil) pada akar sehingga tidak akan terbawa oleh aliran air dalam media.

4. Rhyzodegradation merupakan proses tumbuhan dalam menguraikan zat-zat kontaminan dengan aktivitas mikroba yang berada di sekitar akar tumbuhan.

5. Phytodegradation (phyto transformation) merupakan proses penyerapan polutan oleh tumbuhan untuk proses metabolisme tanaman. Proses ini berlangsung pada daun, batang, akar ataupun di luar sekitar akar dengan bantuan enzim yang dikeluarkan oleh tumbuhan itu sendiri.

6. Phytovalatization merupakan proses penyerapan polutan oleh tumbuhan dan merubahnya menjadi bersifat volatil agar tidak berbahaya lagi untuk selanjutnya diuapkan ke atmosfir (Irawanto, 2010: 3).

Mekanisme penyerapan dan akumulasi logam berat oleh tanaman dibagi menjadi tiga tahapan, yaitu:

1. Penyerapan oleh akar tanaman

Dalam proses penyerapan polutan oleh tanaman, polutan-polutan tersebut harus berbentuk larutan agar dapat diserap oleh akar tanaman. Senyawa-senyawa yang dapat larut dalam air akan diserap oleh akar bersama dengan air sedangkan senyawa-senyawa yang bersifat hidrofobik diserap oleh permukaan tanaman itu sendiri.

2. Translokasi logam dari akar ke bagian tanaman lain.

Dalam proses ini, setelah polutan menembus lapisan endodermis akar tanaman kemudian diteruskan ke bagian atas tanaman melalui jaringan pengangkut (xilem dan floem) ke bagian tanaman lainnya.

3. Lokalisasi logam pada sel dan jaringan

Dalam proses ini tanaman berusaha untuk mencegah keracunan logam terhadap selnya dengan menimbun logam di dalam organ tertentu seperti pada akar agar tidak menghambat proses metabolisme tanaman (Setyaningsih dalam Handayani, dkk, 2013: 4).

Beberapa tanaman yang mampu dijadikan sebagai tanaman hiperakumulator diantaranya: Kenaf (hibiscus cannabinus L.), typha (typha spp.), vetiver (vetiverzizanioides), canna (canna $x$ generalis), cyathula (altemanthera ficoidea cv. "songuinea" (Wang Yan, 2005: 5).

Dalam penelitian ini digunakan tanaman akar wangi (vetiver zizanioides). Keunggulan tanaman akar wangi sebagai hiperakumulator yaitu mampu tumbuh pada berbagai kondisi lingkungan, mudah ditemukan dan 
Affia Patandungan, Syamsidar HS, dan Aisyah Fitoremediasi Tanaman Akar Wangi (Vetiver zizanioides) terhadap Tanah Tercemar Logam Kadmium (Cd) pada Lahan Tpa Tamangapa Antang Makassar

biasanya dianggap oleh masyarakat sebagai tanaman liar yang belum diketahui manfaatnya. Akar tanaman akar wangi diketahui dapat menembus lapisan tanah setebal $15 \mathrm{~cm}$ walaupun pada lapisan yang sangat keras misalnya pada lereng keras dan berbatu. Akar tanaman akar wangi ini mampu menembus lapisan tekstur tanah dengan cara seperti jangkar yang kuat kemudian menahan partikel-partikel tanah melalui akar serabutnya (Gunawan dan Kusumaningrum, 2012: 6).

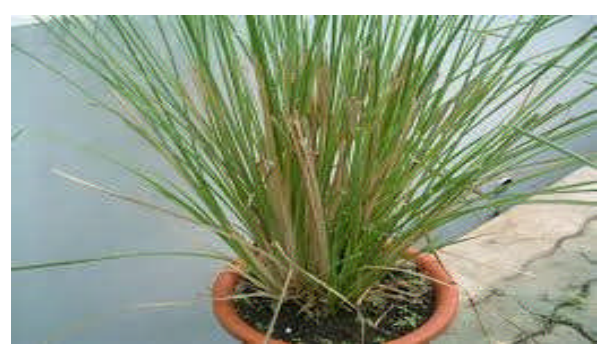

Gambar 2. Tanaman Akar Wangi (Vetiveria zizanioides)

Dalam penelitian ini penambahan kompos berfungsi bagi tanaman dengan kandungan unsur makro dan mikro dalam kompos sehingga daya serap unsur haranya tinggi. Selain itu mikroba yang ada dalam kompos dapat membantu dalam proses fitoremediasi. Mikroba-mikroba tersebut akan berada disekitar akar tanaman berasosiasi dengan logam-logam berat seperti $\mathrm{Cd}$ sehingga mendekati akar tanaman kemudian senyawa pengkhelat (fitokhelatin) yang dikeluarkan oleh tanaman akan mengikat logam-logam tersebut bersama dengan unsur hara lainnya kemudian diteruskan ke bagian lain tanaman.

Logam $\mathrm{Cd}$ merupakan salah satu logam berat berbahaya bagi lingkungan dan manusia. Dampak dari toksisitas logam $\mathrm{Cd}$ seperti terganggunya fungsi ginjal yang dapat mengakibatkan gejala glikosuria, proteinuria, asiduria dan hiperkalsiuria sehingga bila gejala tersebut berlanjut akan menyebabkan gagalnya fungsi ginjal dan mengakibatkan kematian (Darmono, 1999: 28).

Logam Cd merupakan logam yang lunak dan relatif jarang ditemukan di lingkungan. Sebagian logam kadmium dapat larut dalam air dan sebagian lainnya seperti oksidakadmiumdankadmiumsulfidahampirtidak larut. Uap dari logam Cd jika menguap ke atmosfir akan secepatnya teroksidasi sedangkan yang berada dalam tanah kemudian diserap olehtanaman danmemasukirantai makanan tergantung dari jumlah ketersediaan logam Cd dalam tanah (World Bank Group, 1998: 1)

Masuknya logam berat $\mathrm{Cd}$ ke dalam lingkungan menyebabkan logam berat $\mathrm{Cd}$ masuk ke dalam rantai makanan dan masuk ke dalam makhluk hidup khususnya manusia menyebabkan terganggunya sistem fisiologi tubuh manusia 
Affia Patandungan, Syamsidar HS, dan Aisyah Fitoremediasi Tanaman Akar Wangi (Vetiver zizanioides) terhadap Tanah Tercemar Logam Kadmium (Cd) pada Lahan Tpa Tamangapa Antang Makassar

berupa sistem sirkulasi darah dan jantung, sistem respirasi (pernafasan), sistem urin, kerusakan pada sistem reproduksi, sistem syaraf dan kerapuhan tulang. Berdasarkan data badan Standarisasi Nasional yang mengacu pada S.K Dirjen BPOM No. 03725/B/SK/VII/89 tentang ambang batas maksimum cemaran logam Cd dalam makanan adalah $0,2 \mathrm{mg} / \mathrm{kg}$.

Spektrofotometer serapan atom (AAS) merupakan metode analisis kuantitatif untuk menganalisis logam dan beberapa metaloid. Prinsip spektrofotometer serapan atom berdasarkan atas penyerapan energi radiasi yang diserap oleh atom-atom pada keadaan dasar berdasarkan pada unsurnya dan panjang gelombangnya sehingga tereksitasi ke tingkat energi yang lebih tinggi (Khopkar, 1990: 287).

Berdasarkan uraian di atas, maka dilakukanlah remediasi lahan TPATamangapa Antang Makassar yang tercemar oleh logam berat khususnya Cd dengan bantuan tanaman akar wangi.

\section{METODE PENELITIAN}

\section{Alat}

Alat yang digunakan dalam penelitian adalah Spektrofotometer serapan atom (SSA) varian AA240ES, oven, penangas listrik, neraca analitik, cawan penguap/cawan porselin, desikator, pot plastik (ukuran sedang) dan alat gelas yang umum digunakan di laboratorium.

\section{Bahan}

Bahan yang digunakan dalam penelitian ini antara lain tanaman akar wangi (Vetiveria zizanioides), aquabidest $\left(\mathrm{H}_{2} \mathrm{O}\right)$, asam nitrat $\left(\mathrm{HNO}_{3}\right)$ p.a, $\mathrm{HClO}_{4}$ (asam perklorat) p.a, aluminium foil, kertas saring, media tanam (tanah tercemar TPA Tamangapa), kompos dan tissu.

\section{Prosedur Penelitian}

\section{Teknik Sampling}

Sampel yang digunakan berasal dari TPA Tamangapa Antang Makassar. Pengambilan sampel dilakukan secara acak dari beberapa titik berdasarkan tingkat pelapukan sampah yaitu terdiri atas pelapukan 1 tahun, 3 tahun, 5 tahun dan 10 tahun agar representatif.

\section{Tahap Aklimatisasi Tanaman}

Aklimatisasi bertujuan agar tanaman uji tersebut dapat menyesuaikan diri dengan kondisi lingkungan tempat percobaan dan media tanamnya 
Alfia Patandungan, Syamsidar HS, dan Aisyah Fitoremediasi Tanaman Akar Wangi (Vetiver zizanioides) terhadap Tanah Tercemar Logam Kadmium (Cd) pada Lahan Tpa Tamangapa Antang Makassar

sehingga dapat hidup sampai akhir percobaan. Komposisi media tanam berupa perbandingan tanah tercemar (TT) dan kompos (K) yaitu 5 (TT) : $1(\mathrm{~K}), 4,5$ (TT) : 1,5 (K), 4 (TT) : 2 (K) dan sebagai tanaman kontrol $100 \%$ (TT). Penanaman sampel menggunakan pot (ukuran sedang) dengan berat media tanam $6 \mathrm{Kg}$ dengan komposisi media tanam sesuai dengan perlakuan. Tanaman dikatakan stabil apabila tanaman dapat tumbuh subur dan tidak mengalami kematian serta muncul tunas baru.

\section{Analisa logam Cd pada media tanah}

Sebanyak \pm 5 gram sampel ditimbang kemudian ditambahkan $5 \mathrm{~mL}$ $\mathrm{HNO}_{3}$ p.a dan $1 \mathrm{mLHClO}_{4}$ p.a dan didiamkan semalaman. Selanjutnya memanaskan diatas hot plate pada suhu $100^{\circ} \mathrm{C}$ selama 1 jam 30 menit hingga terbentuk endapan putih atau sisa larutan jernih sekitar $1 \mathrm{~mL}$. Filtrat didinginkan kemudian diencerkan dengan aquabidest menjadi $10 \mathrm{~mL}$ kemudian dihomogenkan sampai tanda batas miniskus pada labu takar $100 \mathrm{~mL}$.

\section{Penentuan konsentrasi Cd tanaman dengan AAS}

Diambil 2-3 bonggol ruas dalam setiap tanaman uji. Bagian akar, batang dan daun dibersihkan kemudian dipotong kecil-kecil kemudian dipanaskan dalam oven pada suhu $105^{\circ} \mathrm{C} \pm 2$ jam hingga bobot konstan. Ditimbang kembali untuk mengetahui bobot konstannya selanjutnya menimbang sampel kering sebanyak \pm 5 gram pada neraca analitik. Ditambahkan aquabidest $25 \mathrm{~mL}$ dan $\mathrm{HNO}_{3}$ pekat $5 \mathrm{~mL}$. Memanaskan hingga volumenya $10 \mathrm{~mL}$ hingga terbentuk endapan putih kemudian menambahkan $1 \mathrm{~mL} \mathrm{HClO}_{4}$ pekat. Disaring ke dalam labu takar $100 \mathrm{~mL}$ kemudian menghimpitkan dengan aquabidest hingga tanda batas miniskus dan larutan siap diukur dengan SSA.

\section{HASIL DAN PEMBAHASAN}

Berdasarkan dari hasil penelitian yang dilakukan menujukkan bahwa tanaman Akar Wangi (vetiver zizanioides) mampu mengakumulasi logam berat kadmium (Cd) yang bersumber dari tanah tercemar pada lahan TPA Tamangapa Makassar. Analisis pendahuluan terhadap sampel tanah tercemar menunjukkan konsentrasi logam Cd yang terkandung pada sampel tanah TPA Tamangapa Makassar sebesar 0,116 mg/Kg.

Pengamatan dilanjutkan dengan analisis konsentrasi Cd pada lahan TPA Tamangapa Makassar menggunakan tanaman Akar wangi (vetiver zizanioides) dengan penambahan kompos melalui beberapa perbandingan sebagai stimulan untuk penyerapan logam berat $\mathrm{Cd}$. Adapun perbandingan tanah tercemar 
Alfia Patandungan, Syamsidar HS, dan Aisyah Fitoremediasi Tanaman Akar Wangi (Vetiver zizanioides) terhadap Tanah Tercemar Logam Kadmium (Cd) pada Lahan Tpa Tamangapa Antang Makassar

dengan kompos yang digunakan dalam penelitian ini yaitu [5:1], [4,5:1,5], [4 : 2] dan sebagai tanaman kontrol tanpa penambahan kompos. Pengamatan dilakukan setiap 7 hari sekali selama 28 hari. Adapun konsentrasi Kadmium (Cd) yang mampu diserap oleh tanaman Akar wangi (vetiver zizanioides) tanpa penambahan kompos dapat dilihat pada tabel berikut:

Tabel 2. Konsentrasi Cd pada Tanaman Kontrol (100\% TanahTercemar)

\begin{tabular}{|c|c|c|c|c|c|c|}
\hline \multirow{2}{*}{ Hari } & \multicolumn{2}{|c|}{\begin{tabular}{c} 
Absorbansi Cd (mg/L) \\
\cline { 2 - 7 }
\end{tabular}} & $\begin{array}{c}\text { Absorbansi } \\
\text { Cd rata-rata } \\
\text { (mg/L) }\end{array}$ & $\begin{array}{c}\text { Konsentrasi } \\
\mathbf{C d} \text { (mg/L) }\end{array}$ & $\begin{array}{c}\text { Konsentrasi } \\
\mathbf{C d}(\mathbf{m g} / \mathbf{K g})\end{array}$ & Ket. \\
\hline 0 & 0,0093 & 0,0069 & 0,0081 & 0,0058 & 0,116 & Tanah \\
\hline 7 & 0,0089 & 0.0091 & 0,009 & 0,00746 & 0,25 & Tanaman \\
14 & 0,0059 & 0,0046 & 0,0052 & 0,01197 & 0,24 & $\begin{array}{c}\text { Akar wangi } \\
\text { (vetiver }\end{array}$ \\
21 & 0,0069 & 0,0066 & 0,0067 & 0,01513 & 0,302 & zizanioides) \\
28 & 0,0047 & 0,0064 & 0,00555 & 0,02066 & 0,414 & \\
\hline
\end{tabular}

Tabel 3. Konsentrasi Cd pada Perbandingan [5: 1]

\begin{tabular}{|c|c|c|c|c|c|}
\hline \multirow{2}{*}{ Hari } & \multicolumn{2}{|c|}{$\begin{array}{c}\text { Absorbansi Cd } \\
(\mathbf{m g} / \mathbf{L})\end{array}$} & $\begin{array}{c}\text { Absorbansi } \\
\text { Cd rata- } \\
\text { rata (mg/L) }\end{array}$ & $\begin{array}{c}\text { Konsentrasi } \\
\text { Cd (mg/L) }\end{array}$ & $\begin{array}{c}\text { Konsentrasi } \\
\text { Cd (mg/Kg) }\end{array}$ \\
\cline { 2 - 6 } & 1 & 2 & 0,00705 & 0,00382 & 0,127 \\
\hline 7 & 0,0069 & 0,0072 & 0,0028 & 0,00507 & 0,102 \\
\hline 14 & 0,0028 & 0,0027 & 0,0052 & 0,01105 & 0,222 \\
\hline 21 & 0,0053 & 0,0051 & 0,005 & 0,214 \\
\hline 28 & 0,0019 & 0,0029 & 0,0024 & 0,01073 & \\
\hline
\end{tabular}

Tabel 4. Konsentrasi Cd pada Perbandingan [4,5: 1,5]

\begin{tabular}{|c|c|c|c|c|c|}
\hline \multirow{2}{*}{ Hari } & \multicolumn{2}{|c|}{$\begin{array}{c}\text { Absorbansi Cd } \\
(\mathbf{m g} / \mathbf{L})\end{array}$} & $\begin{array}{c}\text { Absorbansi } \\
\text { Cd rata-rata } \\
\text { (mg/L) }\end{array}$ & $\begin{array}{c}\text { Konsentrasi } \\
\text { Cd (mg/L) }\end{array}$ & $\begin{array}{c}\text { Konsentrasi } \\
\text { Cd (mg/Kg) }\end{array}$ \\
\cline { 2 - 5 } & 1 & 2 & 0,00715 & 0,00401 & 0,133 \\
\hline 7 & 0,0070 & 0,0073 & 0,0034 & 0,00676 & 0,136 \\
\hline 14 & 0,0038 & 0,0030 & 0,0041 & 0,00816 & 0,164 \\
\hline 21 & 0,0041 & 0,0041 & 0,0012 & 0,00694 & 0,138 \\
\hline
\end{tabular}

Tabel 5. Konsentrasi Cd pada Perbandingan [4 : 2] 
Alfia Patandungan, Syamsidar HS, dan Aisyah Fitoremediasi Tanaman Akar Wangi (Vetiver zizanioides) terhadap Tanah Tercemar Logam

Kadmium (Cd) pada Lahan Tpa Tamangapa Antang Makassar

\begin{tabular}{|c|c|c|c|c|c|}
\hline \multirow{2}{*}{ Hari } & \multicolumn{2}{|c|}{$\begin{array}{c}\text { Absorbansi Cd } \\
(\mathbf{m g} / \mathbf{L})\end{array}$} & $\begin{array}{c}\text { Absorbansi } \\
\text { Cd rata-rata } \\
(\mathbf{m g} / \mathbf{L})\end{array}$ & $\begin{array}{c}\text { Konsentrasi } \\
\mathbf{C d}(\mathbf{m g} / \mathbf{L})\end{array}$ & $\begin{array}{c}\text { Konsentrasi } \\
\mathbf{C d}(\mathbf{m g} / \mathbf{K g})\end{array}$ \\
\cline { 2 - 6 } & 1 & 2 & 0,0101 & 0,00951 & 0,316 \\
\hline 7 & 0,0095 & 0,0107 & 0,0028 & 0,00366 & 0,102 \\
\hline 14 & 0,0027 & 0,0028 & 0,0041 & 0,00868 & 0,174 \\
\hline 21 & 0,0042 & 0,0044 & 0,00175 & 0,00868 & 0,174 \\
\hline 28 & 0,0020 & 0,0015 & 0,0038 & \\
\hline
\end{tabular}

Konsentrasi kadmium yang mampu diserap oleh tanaman Akar Wangi dapat terlihat pada Grafik 3.

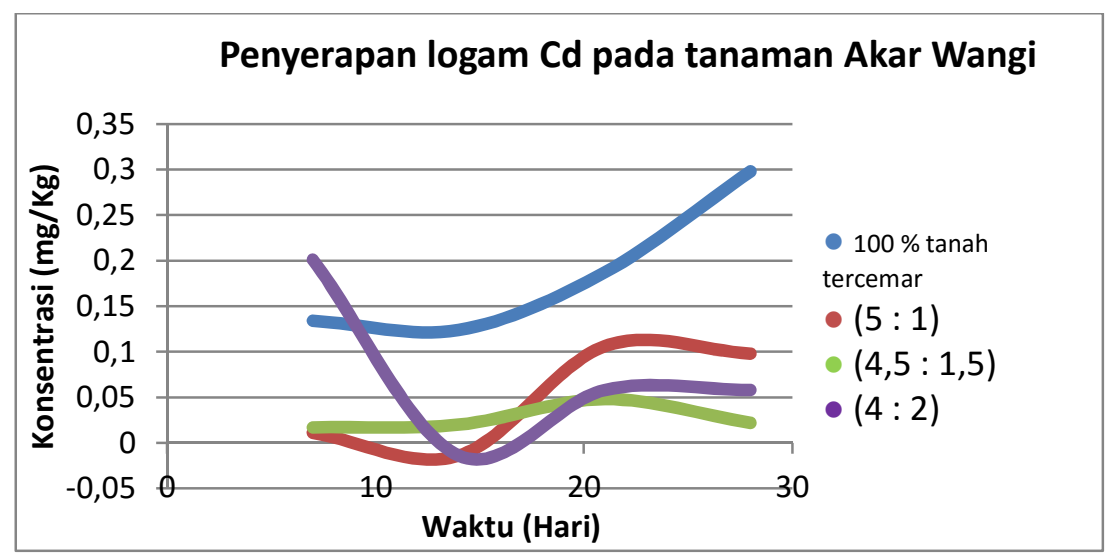

Gambar 3. Grafik Penyerapan Cd pada Tanaman Akar Wangi

Gambar 1 diatas menunjukkan kemampuan tanaman Akar Wangi (Vetiver zizanioides) dalam melakukan penyerapan terhadap tanah tercemar logam Cd. Penyerapan pada tanaman kontrol tertinggi terjadi pada hari ke-28 yakni sebesar 0,298 $\mathrm{mg} / \mathrm{Kg}$, dimana penyerapan konsentrasi $\mathrm{Cd}$ seakan meningkat seiring dengan lamanya waktu kontak.Pada perbandingan [5:1]) dan [4:2] sama-sama mengalami fluktuasi. Sedangkan untuk perbandingan [4,5:1,5] penyerapannnya meningkat hingga minggu ke-3 kemudian menurun pada minggu berikutnya.

Dalam penelitian ini sampel tanah tercemar logam $\mathrm{Cd}$ yang digunakan bersumber dari TPA Tamangapa Makassar dengan menggunakan kompos sebagai stimulan untuk mengetahui daya serap dari tanaman Akar Wangi (Vetiver zizanioides). Perbandingan tanah tercemar (TT) dan kompos (K) digunakan beberapa perbandingan yaitu 5 (TT) : 1 (K), 4,5 (TT) : 1,5 (K), 4 (TT) : $2(\mathrm{~K})$ dan sebagai tanaman kontrol $100 \%$ (TT). Tujuan penambahan 
Alfia Patandungan, Syamsidar HS, dan Aisyah Fitoremediasi Tanaman Akar Wangi (Vetiver zizanioides) terhadap Tanah Tercemar Logam Kadmium (Cd) pada Lahan Tpa Tamangapa Antang Makassar

kompos ini adalah untuk mengetahui pengaruh pemberian kompos dalam proses adsorpsi tanaman Akar wangi (Vetiver zizanioides) terhadap logam berat Cd. Penelitian ini dilakukan selama 28 hari dan analisis tanaman dilakukan setiap 7 hari sekali.

Sampel tanaman Akar Wangi (Vetiver zizanioides) yang akan dianalisis terlebih dahulu dibersihkan kemudian dipotong kecil-kecil. Selanjutnya dihilangkan kadar airnya dengan cara mengoven selama \pm 2 jam pada suhu $105^{\circ} \mathrm{C}$. Sampel kering \pm 5 gram tersebut kemudian didekstruksi basah. Fungsi dari dekstruksi ini adalah untuk memutuskan ikatan senyawa organik dengan logam yang akan dianalisis. Dalam penelitian ini digunakan desktruksi basah karena dekstruksi basah dapat digunakan untuk menentukan unsur-unsur dengan konsentrasi rendah, selain itu dekstruksi kering dapat merusak jaringan tanaman. Selanjutnya sampel kering tersebut ditambahkan aqua bidestilat untuk mencegah terjadinya letupan kecil (bumping) ketika penambahan asam nitrat $\left(\mathrm{HNO}_{3}\right)$ dan asam perklorat $\left(\mathrm{HClO}_{4}\right)$. Fungsi penambahan asam nitrat $\left(\mathrm{HNO}_{3}\right)$ adalah untuk merombak senyawa-senyawa organik dalam sampel serta mengikat logam yang akan dianalisis dan fungsi dari asam perklorat $\left(\mathrm{HClO}_{4}\right)$ sebagai oksidator untuk menghilangkan senyawa penggangu menyempurnakan pada sampel Akar wangi (vetiver zizanioides).

\section{Mekanisme akumulasi logam Cd oleh tanaman Akar wangi (Vetiver zizanioides)}

Dalam mengakumulasi Logam berat seperti kadmium (Cd)akar tumbuhan menyerap logam berat dalam bentuk ion-ion yang larut dalam air seperti unsur hara yang ikut masuk bersama aliran air. Dalam menyerap logam berat, tumbuhan membentuk suatu enzim reduktase di membran akarnya yang berfungsi mereduksi logam. Dari akar kemudian kadmium $\left(\mathrm{Cd}^{2+}\right)$ diangkat melalui jaringan pengangkut, yaitu xilem dan floem, ke bagian lain tumbuhan. Untuk meningkatkan efisiensi pengangkutan, logam diikat oleh molekul khelat (molekul pengikat) (Gosh dan Singh dalam Triastuti, 2011: 9). Kemudian diteruskan ke bagian lain tanaman seperti batang dan daun.

Logam berat seperti Cd akan terakumulasi oleh tanaman akar wangi (Vetiver zizanioides) setelah membentuk senyawa kompleks dengan unsur dan senyawa lain seperti fitokhelatin yang tersusun dari beberapa asam amino seperti sistein dan glisin. Fikokelatin berfungsi membentuk senyawa kompleks dengan logam berat dalam tubuh tumbuhan dan berfungsi sebagai detoksifikasi terhadap tumbuhan dari logam berat, jika tumbuhan itu tidak bisa mensintesis fikokelatin menyebabkan terhambatnya pertumbuhan dan berujung pada kematian. 


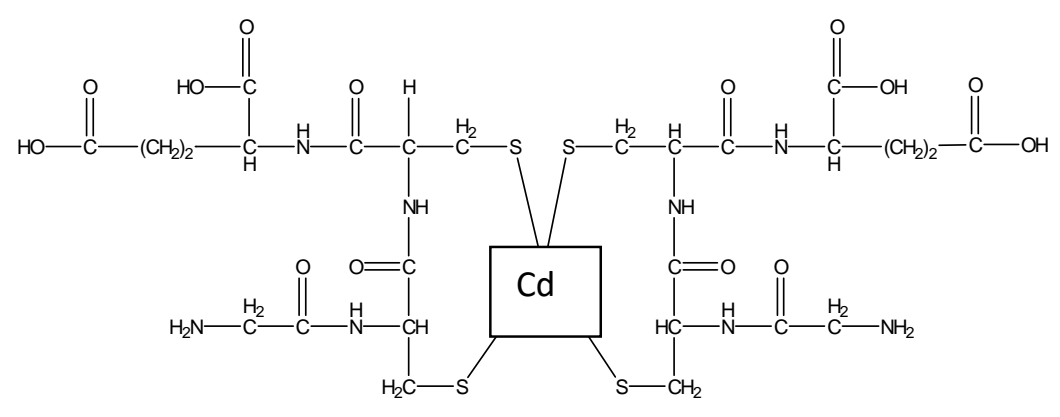

Gambar 2.Senyawa Kompleks Fitokhelatin dan $\mathrm{Cd}^{2+}$

\section{Pengaruh penambahan kompos terhadap penyerapan logam Cd pada tanaman Akar wangi (Vetiver zizanioides)}

Dalam proses fitoremediasi dengan menambahkan kompos sebagai stimulan untuk penyerapan logam berat $\mathrm{Cd}$ maka tumbuhan menstimulasi aktivitas mikroba yang berada pada kompos maupun tanah untuk mendegradasikan logam-logam. Peranan tumbuhan mengeluarkan protein, asam organik maupun senyawa lain yang dibutuhkan oleh mikroba pada akar yang disebut eksudat. Eksudat inilah yang menarik mikroba-mikroba dalam tanah sehingga mendekati akar tanaman yang dikenal dengan istilah kemotaksis sehingga logam-logam yang diserap dapat diteruskan ke jaringan lain tanaman seperti batang dan daun tanaman (Widyati, 2008: 7).

Hasil analisa terhadap akumulasi logam Cd pada tanaman Akar wangi (vetiver zizanioides) dengan penambahan kompos sebagai stimulan mengalami fluktuasi. Hal ini menandakan bahwa penambahan kompos sebagai stimulan kurang signifikan meningkatkan proses fitoremediasi. Seperti pada perbandingan $5(\mathrm{TT}): 1(\mathrm{~K})$ dan perbandingan $4(\mathrm{TT}): 2(\mathrm{~K})$. Hal ini menandakan bahwa tanaman telah mengalami keracunan yang ditandai dengan gejala klorosis dan nekrosis, dapat dilihat perbedaannya dengan jelas pada tanaman akar wangi tanpa penambahan kompos (kontrol). Klorosis merupakan keracunan pada tanaman yang ditandai dengan gejala menguningnya daun tanaman karena kehilangan klorofil sedangkan nekrosis merupakan gejala kematian sel tanaman yang ditandai dengan daun yang menggulung dan daun yang keriput/berparut sehingga proses fisiologis tanaman terganggu dan menyebabkan ketidakmampuan tanaman menyerap logam dalam jumlah yang besar (Rismawati, 2012: 5). Kemudian setelah penyerapan tanaman mengalami penurunan, tanaman melakukan penyerapan kembali. Hal ini disebabkan oleh kemampuan tanaman melakukan mekanisme detoksifikasi melalui sintesis fitokhelatin oleh tanaman akar wangi (vetiverzizanioides) dalam jumlah yang 
Affia Patandungan, Syamsidar HS, dan Aisyah Fitoremediasi Tanaman Akar Wangi (Vetiver zizanioides) terhadap Tanah Tercemar Logam Kadmium (Cd) pada Lahan Tpa Tamangapa Antang Makassar

lebih banyak sehingga tanaman masih bisa bertahan hidup dan mampu mengakumulasi logam $\mathrm{Cd}$ dan ditimbun pada vakuola sehingga penyerapannya meningkat (raya dan ramlah, 2012: 3). Kemudian tanaman juga memiliki kemampuan dalam detoksifikasi ektraseluler yang diakibatkan oleh interaksi antara logam $\mathrm{Cd}$ dengan gugus hidroksil pada selulosa yang melapisi dinding sel tanaman. Penyerapan logam $\mathrm{Cd}$ oleh dinding sel berfungsi untuk mencegah $\mathrm{Cd}$ masuk ke dalam sel atau mengurangi jumlah $\mathrm{Cd}$ yang masuk ke dalam sel sehingga akan mengurangi tingkat keracunan tanaman akar wangi (vetiverzizanioides) sehingga tetap tumbuh (Fauziah, 2011: 50).

Sedangkan perbandingan 4,5 (TT) : 1,5 (K) mengalami kenaikan hingga mingu ke-3 sebesar $0,048 \mathrm{mg} / \mathrm{Kg}$ kemudian mengalami penurunan pada minggu berikutnya sebesar $0,022 \mathrm{mg} / \mathrm{Kg}$. Hal ini disebbakan karena tanaman dalam keadaan lewat jenuh sehingga tidak mmapu lagi melakukan penyerapan yang ditandai dengan gejalan keracunan pada tanaman akar wangi (vetiver zizanioides).

Sedangkan pada tanaman kontrol (100\% tanah tercemar) menunjukkan Presentase penurunan konsentrasi kadmium seakan meningkat seiring dengan semakin lamanya waktu yang digunakan proses fitoremediasi oleh tanaman untuk menyerap logam berat dalam tanah. Penyerapan konsentrasi kadmium tertinggi terjadi pada hari ke-28 yakni sebesar 0,298 mg/Kg. Hal ini disebabkan oleh kemampuan kadmium (Cd) sebagai jenis logam berat yang mampu menguap ke atmosfer, dimana polutan Cd dari dalam tanah yang diserap oleh tanaman akar wangi (Vetiveria zizanioides) ditransformasikan dan dikeluarkan dalam bentuk uap cair ke atmosfer dan kemudian diserap oleh daun. Proses ini yang kemudian disebut fitovolatilisasi.

Dari hasil penelitian terhadap akumulasi logam Cd pada tanaman Akar wangi (vetiver zizanioides) diketahui bahwa tanaman akar wangi (vetiver zizanioides) dapat mengakumulasi logam kadmium (Cd) dari sampel tanah tercemar TPA Tamangapa Makassar. Namun kemampuan akumulasi kadmium (Cd) pada tanaman akar wangi (vetiver zizanioides) belum dapat dikatakan sebagai tanaman hiperakumulator untuk logam $\mathrm{Cd}$ karena hanya menyerap $0,298 \mathrm{mg} / \mathrm{Kg}$.

\section{PENUTUP}

\section{Kesimpulan}

Berdasarkan hasil penelitian dapat disimpulkan bahwa: Tanaman akar wangi (Vetiver zizanioides) mempunyai kemampuan dalam mengurangipencemaran kadmium $\left(\mathrm{Cd}^{2+}\right)$ pada lahan TPA Tamangapa Makassar sebesar 0,298 mg/Kg. Kedua Adanya penambahan kompos sebagai 
Affia Patandungan, Syamsidar HS, dan Aisyah Fitoremediasi Tanaman Akar Wangi (Vetiver zizanioides) terhadap Tanah Tercemar Logam Kadmium (Cd) pada Lahan Tpa Tamangapa Antang Makassar

stimulant tidak memberikan pengaruh signifikan pada kemampuan tanaman akar wangi (Vetiver zizanioides) menyerap Cd.

\section{Saran}

Berdasarkan hasil penelitian penulis menyarankan agar dapat menggunakan tanaman lainnya yang mampu mengakumulasi kadmium dalam tanah dengan metode yang lain seperti metode bioremediasi.

\section{DAFTAR PUSTAKA}

Bahtiar, Ayi, 20007,Polusi Air Tanah Akibat Limbah Industri dan Rumah Tangga Serta Pemecahannya, Bandung: Universitas Padjajaran.

Darmono, 1999, Kadmium (Cd) dalam Lingkungan dan Pengaruhnya Terhadap Kesehatan dan Produktivitas Ternak,Wartazoa, 8(1):28-32.

Fauziah, 2011, Efektivitas Penyerapan Logam Kromium (Cr) dan Kadmium (Cd) oleh Scenedesmus dimorphus, Jakarta: Universitas Islam Negeri Syarief Hidatullah.

Gunawan, G., Nanny Kusmaningrum, 2012,Penanganan Erosi Lereng Galian dan Timbunan Jalan dengan Rumput Vetiver, Bandung:Puslitbang jalan dan Jembatan.

Handayani, et. al., 2013, Efisiensi Fitoremediasi Pada Air Terkontaminasi Cu Menggunakan Salvina Molesta Mitchel, Kediri:Universitas Nusantara PGRI Kediri.

Irawanto, Rony, 2010, Fitoremediasi Lingkungan Dalam Taman Bali,UPT Balai Konservasi Tumbuhan Kebun Raya Purwodadi-LIPI, 2(4):29-35.

Khopkar, S., 2008, Konsep Dasar Kimia Analitik, Jakarta: UI-Press.

Raya, Indah,and Ramlah, 2012, The Bioaccumulation of $\mathrm{Cd}(\mathrm{II})$ ions onEuchemacottoniSeaweedBioakumulasi Ion Cd(II) pada Rumput Laut Euchemacottoni, Makassar: Universitas Hasanuddin, 13(2): 3.

Rismawati, Senja Ike, 2012. Fitoremediasi Tanah Tercemar Logam Berat Zn Menggunakan Tanaman Jarak Pagar (Jatrophacurcas), Surabaya: Institut Teknologi Sepuluh November.

Triastuti, Yuli, 2010, Fitoremediasi Tanah Tercemar Merkuri $\left(\mathrm{Hg}^{2+}\right)$ Menggunakan Tanaman Akar Wangi (Vetiver Zizanioides) Pada Lahan Eks-Tpa Keputih, Surabaya: Institut Teknologi Surabaya.

World Bank Group, 1998,Pollution Prevention and Abatement Handbook, Project Guidelines: Pollutants. 
Affia Patandungan, Syamsidar HS, dan Aisyah Fitoremediasi Tanaman Akar Wangi (Vetiver zizanioides) terhadap Tanah Tercemar Logam Kadmium (Cd) pada Lahan Tpa Tamangapa Antang Makassar

Widyawati, Enny, 2008,Peranan Mikroba Tanah pada Kegiatan Rehabilitasi Lahan Bekas Tambang (Roles of Soil Microbes in Ex-Mining Land Rehabilitation),Pusat Litbang Hutan dan Konservasi Alam, 5(2).

Yan, Wang, 2005,Phytoremediation Of Soil Contaminated With Copper And Zinc From Pig Waste, Malaysia: University Putri Malaysia.

Zubair, Achmad,dan Haeruddin, 2012, Studi Potensi Daur Ulang Sampah Di TPA Tamangapa Kota Makassar,Prosiding 2012 Group Teknik Sipil Universitas Hasanuddin, 6: 1-10. 